\title{
ÎNSOŢIREA RELIGIOASĂ ÎNTRE TRADIȚIE ŞI EVOLUȚIE, LEGISLAȚIE ŞI EDUCAȚIE
}

\author{
Maria A.Ureche * \\ Constantin N. Gheorghiu *
}

Abstract: Wedding ceremony was the object of many analysis over time, particulary because of its importance in the life of many couples but also in society where people live their lives. Considering the legislative initiatives on family, not only in Romania, but also on an European level, this paper's aim is to analysze the wedding ceremony over time, respectively the evolution of wedding ceremony in Europe, including contemporary period. This institution of wedding ceremony was marked by periods of time when it manifested, but also by legislative decision markers which legitimized the state in one form or another. On an European level, without any patterns, there are similarities in lawmakeing, but also in the characteristic particularities for each state. The liks between any state and the church are prooved to be essential, especially on the aspect of wedding ceremony.

Keywords: wedding ceremony, state, legislation, evolution.

\section{Aspecte evolutive în timp și spațiu privind cununia religioasă}

Încă din Antichitate familia era considerată sanctuarul moralei prin care virtuţile private îi iniţiau pe cetăţeni pentru virtuţile publice, dispariţia ei însemnând dispariţia statului (a cetăţii grecoromane şi a divinităţilor acesteia). Căsătoria era instituţia care crea familia şi asigura prosperitatea şi siguranţa statului.

În spaţiul indo-european familia era piatra de temelie a comunităţii (având drept scop împărţirea bunurilor ${ }^{1}$, apărarea şi

\footnotetext{
* PhD, Senior lecturer, Faculty of Law and Social Sciences, "1 Decembrie 1918" University, Alba Iulia, Romania.

* Profesor de religie ortodoxă, Școala Gimnazială Gura Humorului, Suceava, Romania.

${ }^{1}$ Martine Segalen, Historical Anthropology of the Family, Melbourne, 2002, p. 13.
} 
aducerea sacrificiilor pentru divinităţile casnice etc.), căsătoria reprezentând un ritual de trecere dar şi de iniţirere ${ }^{2}$. În Imperiul Roman existau forme vechi de căsătorie care se finalizau prin achiziţionarea lui manus adică trecerea soţiei sub autoritatea soţului sau al capului familiei; căsătoria prin sacrificiu către Jupiterconfarreatio; căsătoria prin vânzare imaginară-coemptio; căsătoria prin decizie liberă-usus. Asemenea tipologii ale căsătoriei le înâlnim şi la popoarele din Orient: sumerieni, hitiţi, egipteni etc. ${ }^{3}$

$\mathrm{Ca}$ şi în spaţiul oriental, lumea greco-romană considera căsătoria ca fiind strâns legată de familie şi de cultul strămoşilor. La aceștia ritualurile erau îndeplinite de capul familiei fiind săvârşite în apropierea vetrei sacre dar şi la mormintele străbunilor aflate în preajma locuinţei familiei. Căsătoria în Grecia era un rit familial plin de semnificaţii religioase, fiind un acord între două familii, realizat de un intermediar care avea un rol sacru în această ceremonie. Acest acord nu avea nici o valoare juridică, nefiind transformat într-un contract.

Căsătoria era un rit de trecere concretizat în mai multe etape: prima etapă numită $\varepsilon \gamma \gamma v \eta \sigma \eta \varsigma$, consta într-un angajament prin care soţul se obliga să-şi ia partenera de soţie. Dacă renunţa trebuia să înapoieze zestrea; a doua etapă consta în conducerea soţiei în casa soţului şi aducerea de ofrande zeilor.

Prin urmare, familia antică avea o altă menire în comparaţie cu cea din secolul nostru, ea fiind alcătuită dintr-un grup de persoane care întreţinea focul sacru şi aducea sacrificii strămoşilor. Această mentalitate era întâlnită şi la Herodot, care înlocuia termenul de familie prin cel de casă. Scopul căsătoriei consta şi în naşterea de prunci, de preferinţă de parte bărbătească, care să continue ceremonia sacră şi să ofere, în continuare, sacrificii strămoşilor, lucru care reiese din formula sacamentală: Ducere uxorem liberum

\footnotetext{
${ }^{2}$ Arnold von Ghennep, The Rites of Passage, London, 2004, p. 123-141.

${ }^{3}$ Pierre Sauzeau, André Sauzeau, La quatrième fonction: altérité et marginalité dans l idéologie des Indo-Européens. Vérité des mythes, Les Belles Lettres, Paris, 2012, p. 311.
} 


\section{$15^{\text {th }}$ International Symposium on Science, Theology and Arts}

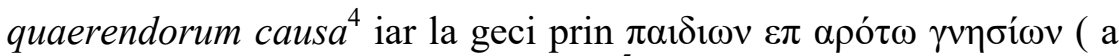
lua de soţie pentru a dobândi copii $)^{5}$. Faptul este evidenţiat şi de legile din cetăţile greceşti şi romane, unde mai marii cetăţii trebuiau să aibă grijă ca nici o familie să nu rămână fără urmaşi şi cultul familiei să dispară. Prin intermediul operelor sale, Cicero îşi îndemna conaţionalii să se îngrijească de templele strămoşeşti ${ }^{6}$ pentru ca acestea să nu dispară iar celibatul era sancţionat prin legislaţia vremii ${ }^{7}$. Bărbatul avea datoria să oficieze cultul strămoşilor, el aparţinând familiei şi numai copiii săi legitimi, rezultaţi din căsătoria

${ }^{4}$ James Parsons, The Ancient Commonwealth, în American Law Register, vol XX, Philadelphia, 1972, p. 477.

${ }^{5}$ Menandru, Dyskolos, 842-844, apud Michael Fontaine, Adele C. Scafuro, The Oxford Handbook of Greek and Roman Comedy, Oxford University Press, New York, 2014, p. 623.

${ }^{6}$ „Ad divos adeunto caste, pietatem adhibento, opes amovento. Qui secus faxit, deus ipse vindex erit. Separatim nemo habessit deos neve novos neve advenas nisi publice adscitos; privatim colunto quos rite a patribus $<$ cultos acceperint $>$. $<$ in urbibus $>$ delubra habento. Lucos in agris habento et Larum sedes. Ritus familiae patrumque servanto. Divos et eos qui caelestes semper habiti sunt colunto et ollos quos endo caelo merita locaverint, Herculem, Liberum, Aesculapium, Castorem, Pollucem, Quirinum, ast olla propter quae datur homini ascensus in caelum, Mentem, Virtutem, Pietatem, Fidem, earumque laudum delubra sunto, nec ulla vitiorum sacra sollemnia obeunto. Feriis iurgia $<\mathrm{a}>$ movento, easque in famulis operibus patratis habento, idque ut ita cadat in annuis anfractibus descriptum esto. Certasque fruges certasque bacas sacerdotes publice libanto $<$ hoc $>$ certis sacrificiis ac diebus" Marcus Tullii Ciceronis, De Legibus Libri, II, 19, ediţie îngrijită de Iohannis Vahleni, Berolini, 1883, p. 9394.

7 „Videtis igitur magistratus hanc esse vim ut praesit praescribatque recta et utilia et coniuncta cum legibus. Ut enim magistratibus leges, ita populo praesunt magistratus, vereque dici potest, magistratum esse legem loquentem, legem autem mutum magistratum... Censoris populi aevitates suboles familias pecuniasque censento, urbis templa vias aquas aerarium vectigalia tuento, populique partis in tribus discribunto, exin pecunias aevitatis ordinis partiunto, equitum peditumque prolem discribunto, caelibes esse prohibento, mores populi regunto, probrum in senatu ne relinquonto. Bini sunto, magistratum quinquennium habento eaque potestas semper esto, reliqui magistratus annui sunto" Marcus Tullii Ciceronis, op. cit., III, 2, 7, p. 162-167. 
religioasă, puteau continua acest cult, trebuind să ofere strămoşilor prânzul funebru .

Prin urmare căsătoria la romani şi la greci avea un caracter sacru, de iniţiere în cultul strămoşilor. $\mathrm{Nu}$ ni s-a păstrat nici un document privind căsătoria civilă, romanii şi grecii nu cunoşteau termenul de ofiţer de stare civilă. Actele pe care le încheiau la căsătorie erau dotale şi cuprindeau zeastrea soţiei, care se putea despărţi foarte uşor, prin refuzul de a oferi ofrande focului sacru şi zeilor casei ${ }^{9}$. La greci, căsătoria $(\gamma \alpha \mu \circ \varsigma)$ era denumită şi $\tau \varepsilon \lambda o \varsigma$ care însemna unire sacră $\breve{1}^{10}$ iar la romani era structurată în trei acte: traditio, deductio in domum şi confarreatio ${ }^{11}$. Soţia era condusă în faţa vetrei sacre unde Penaţii şi străbunii a căror imagini erau păstrate sub forma unor măşti din teracotă primeau libaţiile. Aceasta mânca din pani farreus, simbolizând împărtăşirea dreptului divin cu cel uman: "Nuptiae sunt divini juris et humani communicatio" 12 . Căsătoria era pentru soţie o transformare majoră, ea devenind filiae loco, aparţinând familiei soţului ${ }^{13}$.

Astfel, în dreptul roman, căsătoria consta în transferul lui manus, membrii familiei fiind sub autoritatea lui pater familias (pater la romani fiind cel mai bătrân supravieţuitor al familiei) iar copiii legitimi (matrimonium iustum) erau sub aceeaşi autoritate paternă $\breve{1}^{14}$. Astfel, familia ca număr de persoane era, prin lege, potrivit juristului Ulpian, subiectul puterii (potestas) unei singure persoane:

${ }^{8}$ William Smith, A Smaller Dictionary of Greek and Roman Antiquities, London, 1868, p. 250.

${ }^{9}$ Graham Anderson, Greek and Roman Folklore: A Handbook, Greenwood Press, London, 2006, p. 147.

10 Henry George Liddell, Robert Scott, Henry Drisler, A Greek-English Lexicon, volumul IX, 1883, p. 1539.

${ }^{11}$ James Parsons, op. cit., p. 470.

${ }^{12}$ Bruce W. Frier, Thomas A. J. McGinn, Thomas A. McGinn, A Casebook on Roman Family Law, Oxford University Press, New York, 2004, p. 89.

${ }^{13}$ Ibidem, p. 288.

${ }^{14}$ Ibidem, p.159, 298. 
pater familias, mater familias (dacă soţia era subiectul lui manus) ${ }^{15}$. Descendenţii şi cei care erau adoptaţi depindeau legal de pater familias fiind alieni iuris. După Ulpian, familia reprezenta legăturile între persoanele libere care aveau un strămoş comun. Juristul Gaius afirma că urmaşii devenau sui iuris după moartea lui pater familias iar cel mai în vârstă descendent devenea imediat pater ${ }^{16}$.

În epoca imperială conceptul de căsătorie cuprindea şi un contract dintre două persoane libere pe baza principiului nuptiae consensu contrabentium fiunt adică consimtământul este cel care face nunta. Astfel convieţuirea cu o femeie liberă nu însemna concubinaj ci căsătorie.

În această perioadă de început a creştinismului cetăţenii romani creştini încercau să respecte legile Imperiului după cum reiese din Epitola către Diognet ${ }^{17}$. Deşi în primele secole nu există nici un document care să ateste o slujbă a căsătoriei, totuşi hotărâri ale sinoadelor cuprindeau canoane cu privire la căsătorie iar din

15 „Familiae appellatio refertur et ad corpores cuiusdam Familiae appellatio refertur et ad corporis cuiusdam significationem, quod aut iure proprio ipsorum aut communi universae cognationis continetur. Iure proprio familiam dicimus plures personas, quae sunt sub unius potestate aut natura aut iure subiectae, ut puta patrem familias, matrem familias, filium familias, filiam familias quique deinceps vicem eorum sequuntur, ut puta nepotes et neptes et deinceps. Pater autem familias appellatur qui in domo dominium habet, recteque hoc nomine appellatur, quamvis filium non habeat: non enim solam personam eius, sed et ius demonstramus: denique et pupillum patrem familias appellamus. Et cum pater familias moritur, quotquot capita ei subiecta fuerint, singulas familias incipiunt habere: singuli enim patrum familiarum nomen subeunt. Idemque eveniet et in eo qui emancipatus est: nam et hic sui iuris effectus propriam familiam habet. Communi iure familiam dicimus omnium adgnatorum: nam etsi patre familias habent, tamen omnes, qui sub unius potestate fuerunt, recte eiusdem familiae appellabuntur, qui ex eadem domo et gente proditi sunt", apud ibidem, p. 18.

${ }^{16}$ Brian K. Harvey, Daily Life in Ancient Rome: A Sourcebook, Indianapolis, 2016, p. 45-46

${ }^{17}$ Epitola către Diognet, V, 1-10, în Scrierile Părinţilor Apostolici, trad. de Pr. dr. Dumitru Fecioru, Editura Institutului Biblic şi de Misiune al Bisericii Ortodoxe Române, Bucureşti, 1995, p. 413. 
scrierile Sfinţilor Părinţi ai Bisericii reiese că existau anumite binecuvântări, căsătoria oficiindu-se după liturghie.

La sfârşitul secolului I şi începutul secolului al II-lea creştinii încercau să se distanţeze de ritualurile păgâne, căsătorindu-se cu aprobarea şi binecuvântarea episcopului, după cum reiese din scrierile Sfântului Ignatie de Antiohia: „Fără episcop nu este îngăduit a se săvârşi nici căsătoria. Trebuie ca cele ce se căsătoresc şi cei ce se însoară să facă unirea lor cu aprobarea episcopului"”18.

Caracterul sacru al căsătoriei era evidenţiat şi de Tertulian care afirma că o căsătorie realizată fără aducerea la cunoştinţa episcopului constituia o abatere gravă, taina căsătoriei era pecetluită prin Jerfa Euharistică.

Continuând concepţia Sfântului Apostol Pavel prin care căsătoria simboliza unirea dintre Mântuitorul Iisus Hristos şi Biserică (Efeseni 5, 32), Părinţii Bisericii considerau tinerii căsătoriţi drept un singur trup în care sălăşluia Duhul Sfânt.

După edictul de la Milano (Edictum Mediolanense) din 313 şi libertatea acordată creştinismului încep să apară locaşuri de cult, creştinii putând participa la slujbele Bisericii. Astfel căsătoria trece de la un simplu ritual familial la un ritual creştin constând, în funcţie de provincia imperială, din binecuvântarea episcopului sau a preotului, din velatio nuptialis - înmânarea voalului după cum afirma Sfantul Ambrozie, din $\sigma \tau \varepsilon \varphi \alpha ́ v \omega \mu \alpha$ (încoronare) în Orient, care însemna victoria tinerilor asupra patimilor, după cum afirma Sfântul Ioan Gura de Aur, patriarhul Constantinopolului sau din dextrarum iunctio (intrarea mirilor în camera nupţială) ${ }^{19}$ în Apus etc.

În secolul al IV-lea este atestată ceremonia binecuvântării coroanelor. Acesta era un obicei practicat în Grecia prin care tatăl, după ce-şi dădea fiica în căsătorie, punea pe capetele tinerilor câte o coroană ca simbol al victoriei. În Armenia, în timpul patriarhului

\footnotetext{
18 Sfântul Ignatie Teoforul, Către Policarp, 5, 1, în Scrierile Părinţilor Apostolici, trad. de Pr. D. Fecioru, Editura Institutului Biblic şi de Misiune al Bisericii Ortodoxe Române, Bucureşti, 1979, p. 188.

${ }^{19}$ Jean Gaudémet, Le mariage en Occident: les moeurs et le droit, Les Éditions du Cerf, Paris, 1987, p. 228.
} 
Narses cel Mare (363-372), preoţii binecuvântau coroanele mirilor. Din Armenia această practică a trecut şi în Capadocia unde era atestată la sfârşitul secolului al IV-lea. Potrivit Sfântului Vasile cel Mare şi Sfântului Grigorie de Nazianz înaintea căsătoriei era oficiată logodna. Astfel logodna însemna consimtământul public al persoanei care era însoţit de o garanţie a bunei credinţe, arrha sponsaliciaa adică arvună de logodnă $\breve{a r}^{20}$ urmată de schimbarea inelului, sărutul, unirea mâinilor şi binecuvântarea coaroanei ${ }^{21}$. Sfântul Ioan Gură de Aur îi sfătuieşte pe credincioşi ca să meargă la preoţi "şi să se încheie căsătoria prin rugăciuni şi binecuvântări,"22 .

Mutarea capitalei Imperiului de la Roma la Constantinopol, dar şi problemele militare, demografice, sociale şi economice cu care s-a confruntat Imperiul, au dus la o scădere a aplicării legislaţiei imperiale şi la o prevalare a dreptului cutumiar. Astfel ştiinţa juridică ca şi disciplină de sine stătătoare dispare, în darea legilor implicânduse imperatorul, autorităţile administrative locale sau episcopii.

În Imperiul de Răsărit era legiferată arrha sponsalicia, constând într-un contract legal şi cu consecinţe legale ${ }^{23}$, căsătoria fiind împărţită în două secţiuni cuprinzând logodna ( gr. $\alpha \rho \rho \alpha \beta \omega ́ v-$

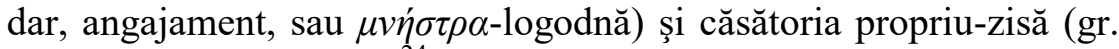
$\sigma \tau \varepsilon \varphi \alpha ́ v \omega \mu \alpha-$-incoronare) $)^{24}$.

În timpul lui Justinian (527-565) exista deja obiceiul ca logodna să fie oficiată împreună cu căsătoria, împăratul dispunând prin Novelele 77 şi 117 ca nobilii să treacă în contract dotalicia

\footnotetext{
${ }^{20}$ Gabriel Le Bras, Jean Gaudemet Sirey, Histoire du droit et des institutions de l'Église en Occident, volumul III, Paris, 1955, p. 523.

${ }^{21}$ St. Gregory of Nazianz, Lettres, trad. P. Gallay, Paris, 1967, p. 122-123.

22 Pr. Lector Dumitru Radu, Caracterul eclesiologic al Sfintelor Taine şi problema intercomuniunii, în Ortodoxia, nr. 1-2(1978), p. 310.

${ }^{23}$ Lucien Anné Desclée, Les rites des fiançailles et la donation pour cause de mariage sous le Bas-Empire, Louvain, 1941, p. 115.

${ }^{24}$ Ibidem.
} 
instrumenta ${ }^{25}$. Pentru cei săraci căsătoria era considerată validă dacă exista oficierea (affectio nuptialis) sau consimţământul (consensus) ${ }^{26}$. Justinian şi-a dorit încă de la început, prin Novela 77, ca toţi cetăţenii creştini să-şi înregistreze căsătoria la un defensor ecclesiae $(\varepsilon \kappa \delta I \kappa \eta \sigma \eta \tau \eta \varsigma \varepsilon \kappa \kappa \lambda \eta \sigma l \alpha \varsigma)^{27}$.

La sfârşitul secolului al VI-lea, căsătoria împăratului Mauriciu (582-602) oficiată de patriarhul din Constantinopol era prezentată în documentele vremii ca fiind o taină divino-umană $(\theta \varepsilon \alpha v \delta \rho ı \kappa \omega v \mu \nu \sigma \tau \eta \rho i ́ o v ~ \mu \varepsilon \tau \varepsilon ́ \delta \omega \kappa \varepsilon v)^{28}$.

Leon al III-lea Isaurul (717-741) întăreşte caracterul sacru al căsătoriei afirmând că pentru cetăţenii săraci care nu-şi puteau permite încheierea unui contract, aceasta avea un caracter legal numai dacă existau consimţământul şi binecuvântarea Bisericii ${ }^{29}$.In Ecloga el distinge două maniere de căsătorie: căsătorie scrisă,

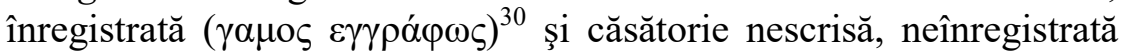
$(\gamma \alpha \mu \circ \varsigma \alpha \gamma \rho \alpha \varphi \circ \varsigma)$, realizată în Biserică, prin declararea în fața

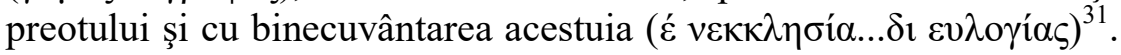
Astfel, în Ecloga 2.9.1 este prezentată viziunea imperială asupra căsătoriei, care era o unire indisolubilă a celor care trăiau în Domnul, bărbatul şi femeia formând un singur trup ${ }^{32}$. Logodna nu mai avea caracterul de promisiune ci ea era un matrimonium initiatum. De asemenea Biserica, prin canonul 98 al sinodului Trulan (692) stabilea că o persoană nu se poate căsători cu altă persoană logodită cu

\footnotetext{
${ }^{25}$ Ibidem.

${ }^{26}$ Alexander P. Kazhdan ed., The Oxford Dictionary of Byzantium, vol. I, New York, 1990, p. 185.

${ }^{27}$ A. Arjava, Women and Law in Late Antiquity, Oxford, 1996, p. 206-207.

${ }^{28}$ Theophylactus Simocattas, Historiae, I, 10, 2-4, ed. C. de Boor, Leipzig, 1887 , p. 57.

${ }^{29}$ M. T. G. Humphreys, Law, Power, and Imperial Ideology in the Iconoclast Era: C.680-850, oxford, 2015, p. 71-73, 250-251.

${ }^{30}$ Ecloga Leonis et Constantini, Epanagoge Basilii Leonis et Alexandri, în Collectio Librorum Juris Graeco-Romani, ed. Carolus Eduardus Zachariae a Lingenthal, Lipsiae, 1852, p. 6-19.

${ }^{31}$ Ibidem.

${ }^{32}$ Ibidem, p. 20.
} 


\section{$15^{\text {th }}$ International Symposium on Science, Theology and Arts}

altcineva, considerând-o adulter ${ }^{33}$. Tradiţia este continuată şi de împăratul Vasile I Macedoneanul (867-886) care dispunea ca taina cununiei să fie oficiată de către un preot în faţa mai multor credincioşi sau martori. În tratatul juridic al împăratului Vasile I, Epanagoga, existau două alternative pentru căsătorie: binecuvântarea

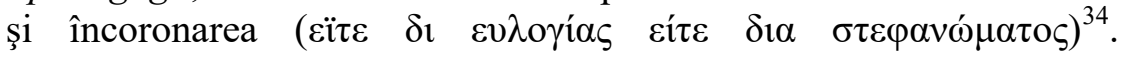
Binecuvântarea ecleziastică devenea principalul criteriu pentru validitatea căsătoriei, contractul $(\delta 1 \alpha \sigma v \mu \beta 0 \lambda \alpha$ íov) fiind opţional pentru cei care nu erau creştini ${ }^{35}$. În această perioadă misionarii greci din Bulgaria practicau binecuvântarea pentru cununie, această practică înlocuind celelalte forme legale ${ }^{36}$.

Împăratul Leon al VI-lea (886-912) prin Novela 89 hotărăşte ca binecuvântarea preotului să fie singura cale prin care căsătoria să fie validă, dând curs cutumei relizate de creștini încă primele secole ${ }^{37}$. Astfel Leon al VI-lea considera omiterea legalizării căsătoriei religioase de către predecesorii săi drept indiferenţă $\breve{s}^{38}$. Logodna făcea parte din actul căsătoriei având consecinţe canonice şi legale. În Novelă sunt exprimate clar: "noi ordonăm căsătoria să fie

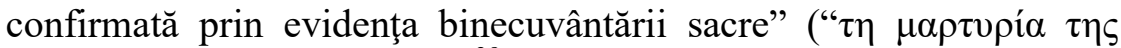

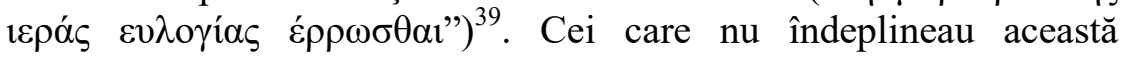
procedură şi se căsătoreau prin alte forme erau consideraţi concubini. Această hotărâre a împăratului Leon al VI-lea este întărită şi în

${ }^{33}$ P. P. Joannou, Discipline generale antique, tome I, Les canons des conciles oecuméniques (II-IX s.), Grottaferrata, 1982, p. 235.

${ }^{34}$ Epanogoga 16,1, în Ecloga Leonis et Constantini, Epanagoge Basilii Leonis et Alexandri, p.106-107.

${ }^{35}$ Ibidem.

${ }^{36}$ Peter L'Huillier, Novella 89 of Leo the Wise on Marriage: An Insight into its Theoretical and Practical Impact, în „Greek Orthodox Theological Review”, vol. 32, nr. 2, 1987, p. 156.

${ }^{37}$ A. Dain, Les Nouvelles de Leon VI le Sage, Paris, 1944, p. 297. P. L'Huillier, op. cit., p. 156-162; John Meyendorff, Căsătoria perspectiva ortodoxă, ediţia a doua, traducere de Cezar Login, Cluj Napoca, Editura Renaşterea/ Editura Patmos, 2012, p. 121.

${ }^{38}$ P. Noailles - A. Dain, Les Novelles de Léon VI le Sage, Paris, 1944, p. $295-$ 296.

${ }^{39}$ P. L'Huillier, op. cit., p. 158. 
Novela 100. Această hotărâre era aplicabilă numai cetăţenilor Imperiului exceptând sclavii.

Din secolul al X-lea Biserica ia hotărâri importante referitoare la căsătorie, prin patriarh şi sinod, interzicând căsătoria a patra $^{40}$. Constantin al IX-lea Monomahul (1042-1055) a continuat

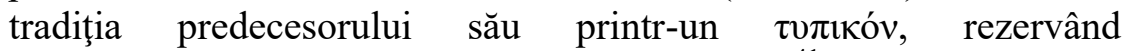
binecuvântarea nupţială episcopului sau preoţilor ${ }^{41}$.

În 1066 patriarhul Ioan al VIII-lea Xiphilinus a prezidat un sinod prin care situa slujba logodnei ca fiind obligatorie şi trebuia săvârşită înaintea cununiei. Această hotărâre sinodală a fost introdusă în legea civilă în luna iunie a anului 1084, de către împăratul Alexios I Comnenul, care prin Novela 24 hotăra ca logodna să fie oficiată cu binecuvântarea preotului, separat de căsătorie, lipsa acesteia invalidând căsătoria ${ }^{42}$. Astfel logodna alături de căsătorie căpăta statut juridic, validând căsătoria. Prin Novela 35 împăratul hotăra ca toţi locuitorii Imperiului (aici fiind incluşi oamenii liberi şi sclavii) să realizeze căsătoria în Biserică, deoarece este un singur Dumnezeu, o singură credinţă, un singur botez ${ }^{43}$.

După căderea Constantinopolului sub turci în 1453, domnitorii ţărilor române s-au erijat în continuatorii împăraţilor bizantini, adoptând ideea de imperium in imperio. Aceştia au preluat o parte din legislaţia bizantină şi din canoanele ecleziastice, utilizau sigiliul cu vulturul bizantin bicefal, se căsătoreau cu domniţe din fostele dinastii imperiale, făceau numeroase donaţii mănăstirilor din Muntele Athos şi ajutau patriarhia ecumenică şi alte mănăstiri de sub stăpânirea otomană, asigurând azil politic refugiaţilor din Constantinopol şi creând un climat de cultură elină la curţile lor. Domnitorii români erau reprezentaţi în iconografie cu coroană şi

\footnotetext{
40 Arhid. prof. dr. Ioan N. Floca, Drept canonic ortodox, legislaţie şi administraţie bisericească, vol. II, Editura Institutului Biblic şi de Misiune al Bisericii Ortodoxe Române, Bucureşti, 1990, p. 76.

${ }^{41}$ V. Grumel, Les Regestes des actes du Patriarchat de Constantinople, Le patriarcat byzantin, series 1, Constantinople, 1936, 2; 923.

${ }^{42} \mathrm{~K}$. Ritzer, Le Mariage dans les Eglises chrétiennes du Ier au IX siècle, Paris, 1962, p. 179-190.

${ }^{43}$ P. L'Huillier, op. cit., p. 158.
} 
veşminte de basilei, fiind unşi de patriarhul ecumenic din Constantinopol $^{44}$. Această continuitate se observă şi în titulatura de domn (lat. dominus) ca având o putere de sorginte divino-umană. La curţile lor, domnitorii români utilizau sistemul juridic bizantin, folosindu-se de Ecloga şi de regulile juridice şi ecleziastice ale călugărului grec Matthaios Blastares: Hexabiblos, Nomocanonul şi

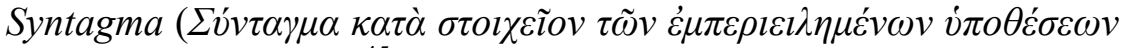

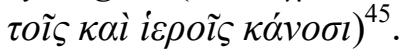

Adoptarea legilor bizantine în ţările române s-a făcut mult mai uşor datorită caracterului lor general care cuprindea o îmbinare între dreptul fiscal, canonic, privat etc. Astfel sistemul juridic s-a caracterizat prin îmbinarea dreptului bizantin cu cel canonic şi cutumiar, concretizat în 1632 printr-o traducere a acestora în limba română de către logofătul Eustatie sub titlul de Pravila aleasă $\breve{a}^{46}$ şi

${ }^{44}$ Nicolae Iorga, Byzance après Byzance, Continuation de l'Histoire de la vie byzantine, Bucarest, 1971, p. 253-275; idem, Vasile Lupu ca urmätor al impăraţilor de Răsărit în tutelarea Patriarhiei de Constanlinopole şi a Bisericii ortodoxe, în Academia Română. Memoriile secţiunii istorice, nr. 36 (19131914), p 207-210; idem, Muntele Athos în legătură cu ţările noastre, în Academia Română. Memoriile secţiunii istorice, nr. 36 (1913 -1914), p. 448515; idem, Fundaţiile religioase ale domnilor români în Orient, în Academia Română. Memoriile secţiunii istorice, nr. 36 (1913-1914), p. 863-870; idem, Donaţiile româneşti pentru mănăstirile din Marea Marmara, în Revista istorică, nr. 7(1921), p. 143-147 ; idem, Legăturile româneşti cu Muntele Sinai, în Academia Română. Memoriile sectiunii istorice, nr. 3 (1932-1933), p. 335346; idem, Domnitorii români Vasile Lupu, Şerban Cantacuzino şi Constantin Brâncoveanu în legătură cu patriarhii Alexandnei, în Academia Română. Memoriile secţiunii istorice, seria a Ill-a, nr. 13 (1932-1933), p. 140-147; Valentin A. Georgescu, L'idée impériale byzantine et la réaction des réalités roumaines (XIVe-XVIIIe siècle). Idéologie politique, structuration de l'Etat et du droit, în Byzantina, nr. 3 (1971), p .325; idem, Byzance et les institutions roumaines jusqu à la fin du XV e siècle, în Actes du XlVe Congrès international des études byzantines, Bucarest, 1971, p. 103-145.

${ }^{45}$ Pan. J. Zepos, Byzantine Law in the Danubian Countries, în Balkan Studies, 7 (1966), p. 343-356.

${ }^{46}$ Cartea este intitulată: Pravilă aleasă, scoasă şi tocmită şi dentru multe svinte scripturi cercată şi găsită, carea de toţi preaînţelepţii şi bunii credincioşi iastecinstită şi priimită, pentru că îndeamnă pre toţi pravoslavnicii spre 
care cuprinde mai multe reglementări juridice privitoare la logodnă şi căsătorie care erau făcute în Biserică precum şi interzicerea anumitor grade de rudenie la căsătorie ${ }^{47}$. Această carte a stat la baza unei alte opere a mitropolitului Varlaam, Şeapte Taine, apărută la Iaşi, în 1744 şi care confirmă sacralitatea oficierii căsătoriei.

Căsătoria a continuat să fie o taină divino-umană, un contract religios această concepţie fiind întărită şi prin hotărârile sinodului de la Trei Ierarhi din Iaşi, ţinut în anul 1642, în timpul domnitorului Vasile Lupu. Membrii sinodului hotărau ca slujba cununiei să fie ţinută în Biserică, deoarece aceasta este o taină.

În anul 1646 a fost tipărită, la Trei Ierarhi, Pravila lui Vasile Lupu intitulată Carte romînească de invăţătură de la pravilele impărăteşti şi de la alte giudeaţe unde există numeroase dispoziţii

cunoştiinţa vieţii şi celor nedeprinş cu tocmala creştinătăţii, tuturor le arată în toate fealiurile calea pocăinţii şi celora ce pre ceastă lume poftesc să lăcuiască de toate pre voie, le spune cum la ceaea de apoi vor să fie sufletele lor la mare nevoie şi pentru îndrăznire să vor aduce pre sine la mare perire şi cu nesocotinţa vor să-ş piiardză toată nevoinţa,pentru că ceia ce nu vor îmbla pre urma cestora dumnedzăieşti învătături,aceia vor să fie ca o turmă de oi fără de păstori, cum scrie şi Svânta Evanghelie: Că oile ceale de turmă înţeleg şi cunosc glasul păstoriului său, apud Lucian Predescu, Contribuţie la viaţa şi opera lui Dragoş-Eustratie Logofătul, în „Glasul Bisericii”, nr. 28 (1969), nr. 9-10, p. 1027-1069; Alin-Mihai Gherman, Profil cultural. Eustratie Logofătul, în Un veac de aur în Moldova (1643-1743), Bucureşti-Chişinău, 1996, p. 135164.

47 Pravila cuprinde următoarele capitole privitoare la căsătoria în Biserică preluate din scrierile lui Matthaios Blastares, Balsamon şi Harmenopulos: „Pentru nunta, când va să facă neştine, cumu să cade să fie amândoo obrazele deopotrivă, ce să dzice de o vârstă, după cum scrie pravila; Pentru rândul nuntei, cum nu să cade pre svântul Postul cel Mare ca să să facă, nice o tocmală sau altă legătură"; Pentru nunta cea dintâiu şi ce iaste nunta şi pentru nunta ce să chiamă cu leage; Pentru tocmala nuntei ce să face fără de blagoslovenia arhiereului şi fără de alte molitve şi svinţiri, ce să fac la nuntă" apud idem, Câteva observatii despre Pravila aleasă a lui Eustratie Logofătul, în Revista Română, anul LX, nr. 1 (2011), p. 74. 
privind familia, statutul juridic al căsătoriei şi acordarea de penitenţe de către Biserică ${ }^{48}$.

În Țara Românească a fost tipărită sub îndrumarea lui Michele Moxalio, Pravila Mică (Parvus Codex Iuris), tipărită la mănăstirea Govora, în anul 1640. Aceasta cuprindea învăţături privitoare la gradele de rudenie şi la căsătorie care trebuia să se facă în Biserică după taina Spovedaniei şi numai cu "blagoslovcenie" (glava 90) ${ }^{49}$.

După mai bine de un deceniu apare, la Târgovişte, Pravila Mare sau Indreptarea Legii cu Dumnezeu, un amplu cod de legi de inspiraţie bizantină, după nomocanoanele lui Manuil Malaxos, Matthaios Blastares şi Alexie Aristen, fiind traduse din limba greacă de Andrei Panoneanu, Pantelimon Ligardi şi Ignatiu Petrizi, cuprinzând norme de drept civil şi penal dar şi canoane bisericeşti. Astfel în glava 198 se hotărăşte că: "se mai chiamă însurarea căce că se împreună şi se fac amîndoi un trup, după cum au zis domnul nostru Isus Hristos, cu molitve şi cu cununie pre leage de la preot" ${ }^{, 50}$.

Potrivit mitropolitului Andrei Şaguna căsătoria era taina care se săvârşea în Biserică, înaintea preotului şi a credincioşilor, validitatea căsătoriei ţinând de respectarea canoanelor bisericeşti ${ }^{51}$.

Conform Codului de legi al domnitorului Ioan Gheorghe Caragea (1812-1818), apărut în 1818, starea civilă a fiecărui cetăţean

${ }^{48}$ Carte romînească de învăţătură 1646, ediţie îngrijită de Andrei Rădulescu, Bucureşti, Editura Academiei Republicii Populare Romîne, 1961, p. 257. Aceste canoane sunt întâlnite şi în Manualul lui Manuil Malaxos dar şi în Pravila aleasă a logofătului Eustatie din 1632 care era în uz la acea vreme.

${ }^{49}$ Pravila bisericească numită cea mică în Colecţiune de legiuirile României vechi şi celei noui, ed. de Ioan M. Bujoreanu, vol. III, Bucureşti, Tipografia Academiei Române, 1885, p. 111

${ }^{50}$ Indreptarea Legii 1652, colecţie îngrijită de Acad. Andrei Rădulescu, Editura Academiei Republicii Populare Romîne, Bucureşti, 1962, p. 195.

51 „Validitatea căsătoriei atârnă dela observarea prescriselor bisericeşti şi civile, care sunt astfel de momentoase, încât neobservându-se acelea, căsătoria este invalidă şi ilegală, şi trag după sine şi nimicirea căsătoriei” apud Andreiu Şaguna, Compendiu de drept canonic al unei Sântei Soborniceşti şi Apostoleşti Biserici, ed. a III-a, Sibiu, 1913, p. 53. 
al Ţării Româneşti se păstra în registre de către mitropolie şi episcopii eparhioţi, fiind completate de preoţi şi protopopi:

„Art. 1 Înscrisurile stării civile slujescu spre dovada celor trei mai de frunte întemplări ale vieţii omului, adică a naşcerii, însurării şi morţii sale. Curata şciinţiă a acestor întemplări este neapăratu de trebuinţiă ca se se cunoscă starea civilă a fiecărui omu, adică loculu şi rangulu ce ţine elu între cei-l'alţi cetăţeni şi în familia sa ... Deci de acum înainte se va ţine în totu cuprinsulu Valachiei condici pentru starea civilă.

Art. 2 Îngrijirea acestei părţii este a Mitropolitului şi a Episcopilor eparchioţi, quare vor priveghea straşnicu ca protopopi şi preoţi să o severşiască cu totă scumpetatea cea cerută de pravilă.

Fie-ce preotu va fi îndatoratu să alcăiescă înscrisurile naşcerii, însurării şi a morţii celor din enoria sua. Aceste înscrisuri vor coprinde anulu, luna şi dio-a întru quare se vor alcătui, numele, porecla, locaşulu, versta şi meseria tutulor celor ce se vor numi într 'ensele; în urmă se vor iscăli de preotu şi de părţile interesate" ${ }^{\text {. }}$.

În Codica ţivilă a Principatului Moldovei, publicată iniţial în

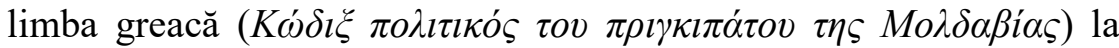
Iaşi, în anul 1816 sub patronajul domnitorului Scarlat Calimach, tradusă şi revizuită la solicitarea logofătului domnesc Costache Conachi care a prezidat o comisie compusă din Petrache Asachi, preşedintele tribunalului din Botoşani şi juriştii Christian Flechtenmacher şi Damaschin Bojinca ${ }^{\mathbf{5 3}}$, în Partea I, intitulată Pentru dritul persoanelor, logodna era considerată ca fiind legală numai

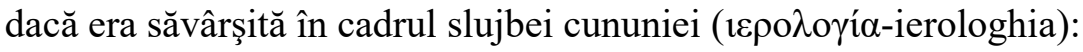

„Art. 64. Logodna este făgăduinţa pentru următórea însoçire, şi se face desăvêrşită séŭ ne-desăvêrşitŭ. Art. 65. Desăvêrşitŭ se face prin íerologie, şi are maǐ totŭ aceeaşı̌ putere ca ênsuşr cununia neputêndu-se deslega fără de câtŭ pentru cuviinciósă pricină.

66. Nedesăvêrşitŭ se face prin góle tocmele şi dare de arvună atuncǐ cândŭ nu urmêză vre uă legiuită îndétorire spre neaperată săvêrşirea

${ }^{52}$ Legiuirea Caragea, Tipografia Naţională a lui Ştefan Rassidescu, Bucureşti, 1865, 205-206.

${ }^{53}$ Ioan M. Bujoreanu, Colecţiune de legiuirile României câte s au promulgatu pene la finele anului 1870, Noua Typographie a Laboratoriloru Români, Bucuresci, 1873, p. 556. 
nunţer̆, ci pricinuesce numaĭ, pagubă logoditeǐ persóne aceĭ ce se lapědă de cununie fără cuviinciósă şi dréptă pricină" ${ }^{\prime \prime}$.

În Manualu de pravila bisericească séu legiuirù trase din canónele Sfinţilorŭ Apostolı̆, ale Sfintelorŭ Sobóre şi ale altorŭ Sfinţı̆ Părinţ̌̆ editat 1851, în în subcapitolul despre nuntă şi formele ei se preciza că:

„Nunta este uă taĭnă prin care duoĕ feçe învoite adică bărbat şi muere se unescŭ de biserică ca să trăiască în totă viaţa lorŭ împreună spre rodire de fir̆. Nunta nu se săvêrşesce de cătŭ cu priimirea amêndurora feçelor şi binecuvêntarea părinţilorŭ lorŭ. Fiindŭ că acestă unire se ţine şi se întăresce prin dragoste şi religie, persónele învoite trebue să mărturisescă aplecarea unuia către altulŭ şi să împlinéscă formele cerute de biserică. Orĭ-ce bărbatŭ înse vrênd a intra în nunta legiuită trebue mai nainte de tote să aibă calităţile cerute de biserică pentru a se însura" $"$.

După publicarea Codului Civil al lui Alexandru Ioan Cuza, căsătoria devenea un act civil, fiind oficiată de către funcţionari publici ca ofiţeri de stare civilă, cu toate că, în acea perioadă, în multe state europene (Grecia Rusia, Bulgaria, Muntenegru, Scoţia etc.), căsătoria rămânea un act religios.

„Art. 49 Înaintea celebrăriǐ căsătorieǐ oficiârulŭ stâriǐ civilı̌ va face douě publicaţiunĭ, în intervalŭ de optŭ dile, în di de Duminică, înaintea uşeǐ bisericeñ enorieǐ şi la uşa caseĩ comunalǐ.

Aceste publicaţiunĭ şi actulŭ ce se va încheia întru acésta, vorŭ cuprinde prenumele, numele profesiunea şi domiciliulŭ amborŭ fiitorilorŭ soţ̌̆, calitatea lorŭ de majorĭ saŭ minorŭ, şi prenumele, numele, profesiunea şi domiciliulŭ taţilorŭ şi mamelorŭ. Acestŭ actŭ va maĭ cuprinde şi dlilele, locul şi ora în carı̆ s'au făcut publicaţiunile; elŭ se va înscrie pe unŭ singurŭ registru, care va fi numerotatŭ şi, parafatŭ, precumŭ este prescrisŭ la articolulŭ 28 , şi care la finele anuluĭ urmeză a se depune la grefa tribunaluluĭ de ântêia, instanţă. ...

Art. 61. În diua otărâtă de pârţile ce voescŭ a se însoţi, după espirarea terminuluĭ de publicaţiunı̆, oficiârulŭ stâriř civilĭ, în casa comunale, în presenţa de patru marturŭ, rude saŭ străinı̆, va da cetire pârţilorŭ de actele susŭ menţionate, relative la statulŭ civile alŭ pârţilorŭ şi la

${ }^{54}$ Ibidem, p. 562.
${ }^{55}$ Ibidem, p. 798. 
formalităţile căsătorieř, şi le va ceti capitolulŭ VI, alŭ titlulul Despre căsătoriă, Despre drepturile şi datorie e respective ale soţilorŭ; elŭ va interpela pe fiitoriǐ soţĭ precum şi persónele cari autorisèză căsătoria, de vorŭ fi de făţă, să declare dacă s'a făcutŭ vre-unŭ contractŭ de căsătoriă şi, la casŭ de afirmativă, data acestuř contractŭ, precum şi numele şi residinţa autoritâţii, care l'a legalisatŭ. Oficiarulŭ stâriî civili va priimi, după acèsta, declaraţiunea fiă-câriı̌ pârţı̆, una după alta, câ voescŭ a se căsători. Elŭ va pronunţa în numele legiĭ câ pârţile sunt unite prin căsătoriă şi va redege îndată, actŭ despre acèsta" ${ }^{56}$.

Prevederile importante privind căsătoria din Codul civil al lui Cuza au rămas neschimbate până în perioada comunistă.

În ceea ce priveşte Transilvania şi Bucovina de sub stăpânire străină a fost aplicată legislaţia austriacă. Dacă la început statul sprijinea Biserica în oficierea căsătoriilor, Iosif al II-lea sub influenţa iluminismului protestant, reformează statul şi diminuează competenţele ecleziastice privitoare la căsătorie şi divorţ, trecându-le în sfera administraţiei civile. Încă din 1786, printr-un decret imperial privitor la regimul căsătoriilor din Transilvania, caracterul sacru al acestora era omis fiind considerate un simplu contract civil. Legea a fost abrogată după moartea lui Iosif al II-lea (20 februarie 1790) şi până în 1894 statul a colaborat cu Biserica în ceea ce priveşte legislaţia căsătoriei, lucru care reiese şi din: Legea căsătoriilor (1850), Codul civil austriac (1853), Legea despre căsătoriile catolicilor în Imperiul Austriac (1856). De la 1 octombrie 1895 în Transilvania au fost introduse registrele de stare civilă care erau păstrate de funcţionarii publici subordonaţi prefectului comitatului care verifica şi legaliza aceste registre până în 1904 când aceste atribuţii au fost transferate în sarcina notarului. După Unirea din 1918 a fost introdusă treptat, legislaţia din Principate ${ }^{57}$.

\footnotetext{
${ }^{56}$ Alecsandru Ion I., Codice civile, Bucuresci, Imprimeria Statului, 1865, p. 1214.

57 Mircea Brie, Reglementări juridice privitoare la familie $\hat{n}$ legislaţia austriacă şi maghiară din a doua jumătate a secolului al XIX-lea, în vol. Politici imperiale în estul şi vestul spaţiului românesc, Editura Universităţii din Oradea/Editura Cartdidact, Oradea/Chişinău, 2010, p. 301-310.
} 


\section{$15^{\text {th }}$ International Symposium on Science, Theology and Arts}

\section{Căsătoria religioasă în state membre UE}

În Cehia, căsătoria religioasă oficiată, în condiţiile prevăzute de lege, de autorităţile bisericeşti autorizate în acest scop are efecte legale. Bază legală o constituie Legea familiei ${ }^{58}$. În procedura preliminară, obligatorie în faţa organelor statului se examinează îndeplinirea condiţiilor legate de capacitatea de a încheia căsătoria, precum şi existenţa sau inexistenţa unui obstacol legal la căsătorie spre exemplu o altă căsătorie sau consangvinitate. Căsătoria religioasă se oficiază de persoana autorizată de orice biserică sau societate religioasă înregistrată de stat, în prezența persoanelor care urmează să se căsătorească şi a 2 martori. În termen de 3 zile lucrătoare de la oficierea căsătoriei, preotul oficiant are obligaţia de a înregistra căsătoria la biroul de stare civilă competent teritorial. Ofițerul de stare civilă înregistrează căsătoria în registrul căsătoriilor şi eliberează soţilor certificatul de căsătorie.

Căsătoria se încheie pe baza consimţământului liber şi complet al bărbatului şi al femeii referitor la încheierea acesteia. Declaraţia se face în faţa funcţionarului municipal la biroul de stare civilă sau în faţa unei autorităţi bisericeşti. Declaraţia se face public, în cadrul unei ceremonii, în prezenţa a 2 martori. $\mathrm{Cu}$ privire la casătoria religioasă, aceasta se oficiază în locul stabilit de reglementările bisericii iar în cazul în care viaţa unuia dintre logodnici este în pericol, căsătoria poate avea loc în orice alt loc.

În Cipru, căsătoria religioasă are validitate legală și se oficiază conform normelor canonice ale bisericii, cu respectarea prevederilor legale cuprinse în Constituţie şi în Legea 104(I)2003 privind căsătoria. Astfel, conform Constituţiei ${ }^{59}$, în baza art.22, dacă viitorii soţi aparţin Bisericii ortodoxe greceşti sau aceleiaşi comunităţi religioase, căsătoria este guvernată de prevederile din Constituţie. În situaţia în care doar unul din viitorii soţi aparţine Bisericii ortodoxe greceşti, iar celălalt nu aparţine acestei Biserici şi

\footnotetext{
58 http://host.uniroma3.it/progetti/cedir/cedir/Lex-doc/Cz 1-94-63.pdf (accesat în ianuarie 5, 2016)

${ }^{59}$ http://www.kypros.org/Constitution/English/ ((accesat în ianuarie 13, 2016) 
nu este membru al Comunităţii Turceşti, căsătoria este guvernată de Legea 104(I)/2003 privind căsătoria. Totuşi, viitorii soţi pot opta pentru căsătoria reglementată de Constituţie. Dacă unul din viitorii soţi aparţine unui grup religios, iar celălalt nu aparţine aceluiaşi grup religios şi nu este membru al Comunităţii Turceşti, căsătoria este guvernată de Legea 104(I)/2003 privind căsătoria. Totuşi, părţile pot opta pentru căsătoria reglementată de Constituţie. Dacă nici unul din viitorii soţi nu aparţine Bisericii ortodoxe sau unui grup religios şi nici Comunităţii Turceşti, căsătoria este guvernată de Legea 104(I)/2003 privind căsătoria.

În art. 3 al Legii 104(I)/2003, căsătoria semnifică uniunea, prin contract matrimonial, dintre o femeie şi un bărbat, celebrată de un ofițer de stare civilă în conformitate cu prevederile acestei legi sau de un cleric autorizat ${ }^{60}$ în conformitate cu canoanele Bisericii ortodoxe greceşti sau ale doctrinelor cultelor religioase recunoscute de Constituţie. Căsătoria se oficiază prin declararea simultană a consimţământului la căsătorie de către persoanele care intenţionează să se căsătorească şi citirea de către ofiţ̧erul de stare civilă a textului legal în acest sens. Declaraţia se face în public şi formal, în prezenţa a cel puţin 2 martori, în faţa ofiţerului de stare civilă, care are obligaţia de a întocmi certificatul relevant. Imediat după celebrarea căsătoriei, ofiţerul de stare civilă emite, un certificat, în 3 examplare, semnat de el însuşi, de părţi şi de cel puţin 2 martori. Un exemplar se înmânează părţilor la căsătorie, al doilea se transmite, în termen de 7 zile, registratorului şi cel de-al treilea se îndosariază la registrul ţinut de registratorul de căsătorii. De remarcat faptul că, la cererea persoanei în cauză, certificatul de căsătorie poate fi emis în limba engleză. Locul desfășurării ceremoniei căsătoriei poate fi ales de miri

${ }^{60}$ Ministrul de interne poate înregistra, la cerere, clerici nou autorizaţi sau recunoscuţi de orice religie, cult sau organ religios, după verificarea efectuată de şeful cultului recunoscut căruia îi aparţin. Numele clericilor autorizaţi se înregistrează într-un registru special şi se publică în Gazeta Oficială a Republicii în luna ianuarie a fiecărui an. În orice moment, ministrul de interne poate radia din registru numele clericului autorizat, în colaborare cu şeful cultului căruia îi aparţine clericul în cauză. 
și poate fi la sediul municipalității sau la locul indicat de orice alt ofițer de stare civilă ${ }^{61}$.

În Danemarca, căsătoriile religioase sunt guvernate de Legea privind încheierea şi desfacerea căsătoriei ${ }^{62}$. Căsătoriile religioase au efecte civile legale și pot fi oficiate, în condiţiile legii, în cadrul celor 3 categorii de comunităţi religioase: Biserica evanghelică luterană (Biserica Naţională), comunităţile religioase recunoscute şi autorizate, alte comunităţi religioase şi societăţi cu caracter religios. Fiecare dintre acestea este guvernată de prevederi legale specifice. Ceremonia de căsătorie se desfăşoară obligatoriu în prezenţa a cel puţin 2 martori. Căsătoriile religioase oficiate în afara Bisericii evanghelice-luterane pot fi celebrate de preoţii special autorizaţi în acest scop de Ministerul pentru probleme religioase, autorizarea reprezentând o condiţie de validitate a efectului legal al căsătoriei religioase.

În Finlanda, căsătoria religioasă este guvernată de prevederile Legii privind căsătoria ${ }^{63}$, precum şi de normele religioase proprii Bisericii evanghelice luterane, Bisericii ortodoxe greceşti sau comunităţii religioase din care fac parte viitorii soţi. Biroul de stare civilă are obligaţia de a verifica existenţa sau inexistenţa impedimentelor legale la căsătorie. De asemenea, verificarea impedimentelor la căsătorie poate fi efectuată de parohia Bisericii evanghelice luterane sau a Bisericii ortodoxe greceşti, dacă viitorii soţi sau unul dintre aceştia aparţin Bisericii respective. Dacă persoana care examinează impedimentele la căsătorie constată că nu există nici un impediment legal la căsătorie, aceasta eliberează un certificat în acest sens. Certificatul se eliberează după expirarea unui

${ }^{61}$ Orice persoană care, cu bună ştiinţă, oficiază sau pretinde că oficiază o căsătorie fără a avea competenţa legală în acest sens, comite o infracţiune şi este sancţionat cu închisoare de până la 5 ani, cu amendă de maximum $8.500 €$ sau cu ambele pedepse.

62 The Formation and Dissolution of Marriage Act, http://host.uniroma3.it/progetti/cedir/cedir/Lex-doc/Dk_marrig.pdf (accesat în februarie 3, 2016)

63 http://www.finlex.fi/fi/laki/kaannokset/1929/en19290234.pdf (accesat în februarie 10, 2016) 
termen de 7 zile de la depunerea cererii de examinare a impedimentelor la căsătorie. Totuşi, dacă există motive întemeiate, certificatul poate fi eliberat mai devreme. Ceremonia de căsătorie, atât civilă cât şi religioasă, se desfăşoară în prezenţa rudelor sau a altor martori. Ceremonia religioasă poate fi oficiată într-o biserică evanghelică luterană, într-o biserică grecească ortodoxă sau într-o altă comunitate religioasă căreia Ministerul Educaţiei i-a aprobat licenţa de oficializare a căsătoriilor.

În Germania, până în anul 2009, conform art.1310 din Codul civil, căsătoria civilă era obligatorie. De la 1 ianuarie 2009, conform modificărilor aduse Legii privind starea civilă, căsătoriile religioase au efecte legale. Pentru prima dată după 134 de ani, căsătoria religioasă nu trebuie precedată de căsătoria civilă. Efectele legale ale căsătoriei religioase sunt mai restrânse faţă de cele ale căsătoriei civile. Astfel, cuplurile căsătorite religios nu beneficiază de dreptul de moştenire sau pensie alimentară în caz de divorţ şi nici de facilităţile fiscale acordate persoanelor căsătorite civil.

În Grecia, în baza art.1367 din Codul civil ${ }^{64}$, căsătoria poate fi oficiată atât de autorităţile civile competente, cât şi de autorităţile religioase. Până în 1982, cînd a fost adoptată Legea nr. $1250^{65}$, care a introdus validitatea căsătoriei civile, numai căsătoria religioasă avea efecte legale. Căsătoria religioasă poate fi oficiată de preotul bisericii ortodoxe sau de oficiantul unei alte religii recunoscute în Grecia. Preotul ortodox care oficiază căsătorii trebuie abilitat în acest sens de către autorităţile competente ale bisericii. Independent de forma căsătoriei, civilă sau religioasă, fiecare din viitorii soţi trebuie să depună dosarul de căsătorie la primăria locului de domiciliu. În aceeaşi zi, cererea de căsătorie este afişată la sediul primăriei. Dacă viitorii soţi domiciliază într-un oraş mare, dosarul trebuie să cuprindă şi un exemplar al ziarului local aferent domiciliului solicitantului, în care s-a publicat anunţul de căsătorie. În cazul existenţei unui

\footnotetext{
${ }^{64}$ Commission Internationale de l'État Civil, Guide pratique international de l'état civil - Grèce

http://www.ciec1.org/GuidePratique/index.htm (accesat în februarie 18, 2016)

${ }^{65}$ Legea nr.1250/1982 privind căsătoria
} 


\section{$15^{\text {th }}$ International Symposium on Science, Theology and Arts}

impediment la căsătorie sau al neîndeplinirii unei condiții legale, orice persoană poate face opoziţie la căsătorie. Opoziţia, însoţită de elementele de motivare, se face în termen de o săptămână de la publicarea cererii de autorizare a căsătoriei. După constatarea îndeplinirii condiţiilor legale necesare pentru încheierea căsătoriei şi după efectuarea publicităţii, viitorilor soţi li se eliberează autorizaţia de căsătorie.

Orice căsătorie religioasă ${ }^{66}$ trebuie transcrisă în registrele de stare civilă, pe baza prezentării certificatului eliberat de preotul care a oficiat căsătoria, în termen de 40 de zile de la data celebrării acesteia. Funcţionarul de stare civilă poate înregistra căsătoria şi după expirarea acestui termen, în cel târziu 3 luni de la oficierea căsătoriei. Conform art.31 din Legea nr.344/1976 ${ }^{67}$, certificatul de căsătorie trebuie să conţină, suplimentar datelor prevăzute de lege pentru toate actele de stare civilă, unele informaţii, spre exemplu, în cazul căsătoriei religioase, sunt indicate religia şi ritualul celebrării, numele şi prenumele preotului care a oficiat căsătoria, precum şi referinţele privind autorizaţia de încheiere a căsătoriei. Deşi legea din 1982 a anulat unele din impedimentele la căsătorie prevăzute de Codul civil, pentru căsătoria religioasă, Biserica Greciei a hotărât menţinerea mai multor impedimente. De exemplu, sunt considerate impedimente la căsătoria religioasă: faptul că unul din viitorii soţi nu este ortodox; existenţa a trei căsătorii anterioare; apariţia, după creştinare, între viitorii soţi, a unei relaţii strânse de afinitate; faptul că viitorii soţi au fost condamnaţi pentru adulter, prin hotărâre judecătorească (deşi adulterul nu mai este incriminat de legea penală); interdicţia la căsătorie aplicată preoţilor şi călugărilor; dreptul unei femei de a se recăsători numai după expirarea unui termen de 10 luni de la desfacerea căsătoriei anterioare.

${ }^{66}$ Charalambos K. Papastathis, Greece: A Faithful Orthodox Christian State. The Orthodox Church in the Hellenic Republic, International Center for Law and Religious Studies

http://www.iclrs.org/content/blurb/files/Greece.2.pdf (accesat în februarie 23, 2016)

${ }^{67}$ Legea nr.344/1976 privind actele de stare civilă. A se vedea și Decretul prezidenţial nr.850/1976 privind modalităţile de aplicare a Legii nr.344/1976 
În Irlanda, cuplurile se pot căsători civil sau religios. Căsătoria religioasă este recunoscută de lege ca fiind un contract civil. Baza legală o regăsim în legea din anul 2004 privind înregistrarea civilă ${ }^{68}$. Căsătoria religioasă se încheie conform tradiţiilor şi ritualurilor comunităţii religioase căreia îi aparţin viitorii soţi, cu respectarea condiţiilor prevăzute de legea civilă. Căsătoria religioasă poate fi oficiată numai de episcopul, pastorul sau preotul înregistrat în Registrul oficianţilor de căsătorii ţinut de Biroul general de stare civilă şi autorizat în acest scop de registratorul general. În registru figurează atât ofiţerii de stare civilă, cât şi membrii comunităţilor religioase nominalizaţi de acestea ca oficianţi de căsătorii. Ceremonia religioasă trebuie să se desfăşoare în prezenţa a 2 martori care au împlinit vârsta de 18 ani, într-o biserică sau aşezământ religios autorizat, certificat sau înregistrat pentru oficierea căsătoriilor. De regulă, căsătoria în bisericile catolice, are loc în biserica din parohia miresei.

Cu 3 luni înainte de data căsătoriei, viitorii soţi trebuie să notifice personal intenţia de căsătorie la biroul de stare civilă teritorial competent. Neîndeplinirea acestei condiţii are ca efect invalidarea căsătoriei. Dacă la oficiul de stare civilă se trimite o singură notificare, aceasta trebuie semnată de ambii viitori soţi. De asemenea, în faţa funcţionarului de stare civilă, fiecare din viitorii soţi semnează o declaraţie privind inexistenţa impedimentelor la căsătorie. În cazul în care constată că au fost prezentate toate informaţ̧iile necesare şi că nu există nici un impediment la căsătorie, funcţionarul de stare civilă înmânează fiecăruia din viitorii soți formularul de înregistrare a notificării intenţiei de căsătorie. În momentul celebrării căsătoriei, formularul document se prezintă oficiantului. Formularul, semnat de ambii soţi, de cei 2 martori şi de oficiant imediat după încheierea ceremoniei religioase, se trimite, în termen de o lună, pentru înregistrare, la biroul de stare civilă.

68

Civil

Registration

Act, http://www.irishstatutebook.ie/2004/en/act/pub/0003/index.html (accesat în februarie 29, 2016) 
În Italia, până în anul 1929, anul încheierii Tratatului (Concordatului) dintre Sfântul Scaun şi Republica Italiană, din cauza separaţiei rigide dintre Biserică şi Stat, căsătoria religioasă nu era recunoscută de către stat. Conform art.8 din Tratat (Recunoaşterea căsătoriei), preotul catolic care oficiază căsătoria religioasă are competenţa de a elibera certificatul de căsătorie, care, ulterior, se depune la registratura municipală. Căsătoria religioasă este validă din momentul oficierii religioase, nu din momentul eliberării certificatului. Tratatul prevede impedimentele canonice la căsătorie, precum şi condiţia publicităţii căsătoriei la primărie. Căsătoria religioasă catolică se desfăşoară conform unei proceduri similare cu cea a ceremoniei civile de căsătorie. Căsătoria religioasă trebuie transcrisă în registrul de stare civilă al statului. Transcrierea conferă căsătoriei efecte legale iar în absenţa transcrierii, căsătoria nu are efecte civile.

Încheierea căsătoriei este precedată de publicarea anunţului privind intenţia de căsătorie de către funcţionarul biroului de stare civilă competent teritorial. Cererea de publicitate se face de viitorii soţi. La depunerea cererii, se depun documentele necesare dovedirii libertăţii matrimoniale precum și o declarație pe proprie răspundere privind inexistenţa gradelor de rudenie. Anunţul privind intenţia de căsătorie este afişat la primărie pe o perioadă de minimum 8 zile, care trebuie să includă două duminici succesive. Dacă nu se primește nici o notificare de opoziţie la căsătorie şi nu sunt impedimentelor la căsătorie, viitorilor soţi li se eliberează un certificat în acest sens. Bisericile catolice impun cerinţa ca ambele părţi să fi fost creştinate şi confirmate ca membri ai bisericii catolice. De asemenea, viitorii soţi trebuie să urmeze un curs prematrimonial religios, curs care durează cel mult 2 luni și este organizat de biserică.

În cazul căsătoriei celebrate conform dreptului canonic, preotul catolic oficiant are şi calitatea de funcţionar de stare civilă al statului. Ca parte a ceremoniei, în faţa cuplului şi a martorilor oficiali, acesta citește drepturile şi îndatoririle soţilor, aşa cum apar în Codul civil. După încheierea ceremoniei, preotul eliberează, în 2 exemplare, certificatul de căsătorie, semnat de ambii soţi şi de martori. Un exemplar se înmânează soţilor, iar cel de-al doilea este 
trimis, în termen de 5 zile, la biroul de stare civilă teritorial competent, în vederea înregistrării. Transcrierea în registru a căsătoriei se face în 24 de ore de la primirea documentului şi este notificată preotului oficiant.

În Letonia, conform art.51 din Codul civil ${ }^{69}$, viitorii soți care aparţin uneia din religiile: evanghelice luterane, romano-catolice, ortodoxe, vechi credincioşi, metodiste, baptiste sau adventiste de ziua a 7-a pot fi căsătoriţi religios de preotul autorizat, în acest scop, de liderul comunităţii religioase în cauză. Dacă nu au fost ridicate obiecţii la căsătorie sau dacă acestea au fost respinse, căsătoria poate fi oficiată la oficiul de stare civilă sau, pe baza cererii privind intenţia de a se căsători care conţine o notiţă referitoare la publicitate, poate fi oficiată de preotul unei biserici sau la un alt oficiu de stare civilă. Oficierea căsătoriei este guvernată de prevederile Codului civil şi ale Legii privind starea civilă ${ }^{70}$, precum şi de reglementările religioase specifice comunităţii căreia îi aparţin viitorii soţi. În termen de 40 de zile de la oficierea căsătoriei, şi pentru fiecare căsătorie oficiată, preotul transmite oficiului de stare civilă din raza teritorială în care a avut loc căsătoria, informaţiile necesare pentru înregistrarea în registrul de căsătorii. Preotul care nu îndeplineşte această obligaţie poate răspunde administrativ.

În Malta, Acordul încheiat între Sfântul Scaun şi Republica Malta privind recunoaşterea efectelor civile ale căsătoriilor canonice şi a deciziilor autorităţilor şi tribunalelor ecleziastice asupra acestor căsătorii reglementează efectele civile ale căsătoriilor oficiate conform normelor canonice ale bisericii catolice. Principiile consacrate în Acord au fost transpuse în legislaţia internă de Legea din anul 1995 pentru modificarea Legii privind căsătoria. Oficierea căsătoriei trebuie precedată de publicarea anunţului de căsătorie. Publicarea anunţului de căsătorie constă în afişarea acestuia la biroul

${ }^{69}$ The Civil Law,

http://www.ur.gov.lv/faili/ENGLISH\%20Normativie\%20akti/civillikums.doc

(accesat în februarie 22, 2016)

${ }^{70}$ Civil Status Documents Law

http://www.vvc.gov.lv/export/sites/default/docs/LRTA/Likumi/Civil_Status_D ocuments_Law.doc (accesat în februarie 26, 2016) 
de stare civilă, pe o perioadă de minimum 8 zile consecutive, fără a fi incluse zilele de sâmbătă, duminică sau alte zile de sărbătoare legală. De asemenea, anunţul se afişează în oraşul, satul sau parohia din Malta în care domiciliază fiecare dintre viitorii soţi. Anunţul de căsătorie se publică pe baza cererii semnate de viitori soți.

Căsătoria se poate încheia în formă civilă ${ }^{71}$, sau în formă religioasă. Căsătoria civilă sau religioasă este validă numai dacă sunt îndeplinite sau respectate toate prevederile prezentei legi aplicabile acesteia sau căsătoriei, în general. Toate căsătoriile se încheie în prezenţa a cel puţin 2 martori. Căsătoria religioasă se încheie conform ritualurilor şi uzanţelor unei biserici sau religii recunoscută şi căreia îi aparţin unul sau ambii din viitorii soţi sau în cadrul căreia profesează unul sau ambii viitori soţi. Actul de căsătorie se completează şi se transmite pentru înregistrare, imediat după căsătorie. Preotul parohiei trimite actul de căsătorie la biroul public de stare civilă, pentru înregistrare, în termen de 5 zile lucrătoare de la oficierea căsătoriei. După înregistrarea actului de căsătorie, directorul biroului public de stare civilă notifică înregistrarea preotului parohiei care a transmis actul de căsătorie.

În Marea Britanie conform Legii din anul 1949 privind căsătoria, există 4 tipuri de ceremonii de căsătorie ale căror efecte legale sunt recunoscute: căsătoria civilă, căsătoria oficiată conform riturilor Bisericii Angliei, căsătoria prin ceremonie religioasă nonanglicană și căsătoriile evreieşti şi cele ale sectei protestante Quaker. Căsătoria trebuie înregistrată în registrul de căsătorii al bisericii. Certificatul de căsătorie trebuie semnat de către soţi, de cel puţin 2 martori și de persoana autorizată care a oficiat căsătoria. În lipsa acestei autorizaţii, la căsătoria religioasă este necesară prezenţa funcţionarului de stare civilă.Toţi preoţii bisericilor anglicane sunt autorizaţi să înregistreze căsătoriile religioase pe care le oficiază.

Căsătoria poate avea loc într-o biserică anglicană dacă se face dovada că:

\footnotetext{
${ }^{71}$ Civil Code, http://www.justiceservices.gov.mt/DownloadDocument.aspx?app=lom\&itemid $=8580$ (accesat în martie 3, 2016)
} 
- unul din soți: a locuit în parohie o perioadă de minimum 6 luni sau a fost botezat în respectiva parohie sau s-a pregătit pentru confirmare în respectiva parohie sau a participat la serviciile religioase obişnuite ale bisericii o perioadă de cel puţin 6 luni.

- unul din părinţii viitorilor soţi, în orice perioadă de după naşterea acestuia: a locuit în parohie o perioadă de cel puţin 6 luni sau a participat la serviciile religioase obişnuite ale bisericii o perioadă de cel puţin 6 luni.

- unul din părinţii sau bunicii unuia din viitorii soţi s-a căsătorit în biserica respectivei parohii.

Anunţul privind intenţia de căsătorie trebuie citit în biserica fiecăruia dintre viitorii soţi, precum şi în biserica în care urmează a avea loc căsătoria, dacă aceasta este diferită de una din bisericile mai sus menţionate. Anunţul se citeşte în biserică în 3 duminici în perioada de 3 luni care precedă căsătoria. Pentru persoanele care nu au împlinit vârsta de 18 ani este necesar consimţământul părinţilor iar minorii sub 16 ani nu au dreptul să se căsătorească. Pentru a fi legală, căsătoria trebuie să aibă loc între orele 8,00 şi 16,00, în orice zi a săptămânii, în prezența a 2 martori. De regulă, căsătoriile au loc duminica. Din anul 2002, în anumite circumstanţe, biserica poate accepta oficierea religioasă a căsătoriei unei persoane care a fost căsătorită religios şi a divorţat. Oficierea căsătoriei de către un alt preot decât cel al bisericii în care are loc ceremonia este posibilă, cu condiţia ca acesta să aparţină bisericii anglicane, şi cu acordul preotului bisericii în care se oficiază căsătoria.

În Polonia, s-a revizuit Codul familiei în anul 1998, ca urmare a ratificării Tratatului cu Sfântul Scaun. S-a introdus, astfel, posibilitatea viitorilor soţi de a opta între o căsătorie civilă şi o căsătorie canonică. Căsătoria canonică are efecte civile legale. În baza art.10 din Tratat, căsătoria canonică catolică are aceleaşi efecte pe care le are căsătoria încheiată conform legii poloneze. Căsătoria religioasă are efecte civile ${ }^{72}$ dar în cazul căsătoriei religioase,

\footnotetext{
${ }^{72}$ Commission Internationale de l'État Civil, Guide pratique international de l'état civil - Pologne

http://www.ciec1.org/GuidePratique/index.htm (accesat în martie 5, 2016)
} 


\section{$15^{\text {th }}$ International Symposium on Science, Theology and Arts}

certificatul de căsătorie se întocmeşte de ofiţerul de stare civilă. În absenţa înregistrării, căsătoria religioasă nu are efecte civile.

Oficierea căsătoriei religioase având efecte legale nu este limitată numai la biserica catolică, ci poate avea loc şi în cadrul altor comunităţi religioase: ortodoxă, evanghelică-Augsburg, evanghelică reformată, evanghelică metodistă, baptistă, adventistă de ziua a 7-a, penticostală şi evreiască. Căsătoriile încheiate în aşezămintele religioase musulmane sunt considerate ca fiind ceremonii religioase fără caracter legal şi obligatoriu. În consecinţă, pentru a avea efect legal, căsătoria religioasă trebuie precedată de căsătoria civilă. Ministrul de interne publică lista reprezentanţilor fiecărei biserici sau asociaţii de cult care au competenţa oficierii de căsătorii religioase cu efecte civile.

Ceremonia catolică de căsătorie prevede obţinerea certificatului de constatare a inexistenţei impedimentelor la căsătorie. Ofiţerul de stare civilă competent eliberează viitorilor soţi care doresc oficierea unei căsătorii religioase, un certificat constatator al inexistenţei impedimentelor la căsătorie, după o verificare prealabilă. În lipsa acestui certificat constatator, căsătoria religioasă nu îşi produce efectele civile. Deasemenea, viitorii miri depun la biserica în care urmează a avea loc căsătoria, certificatul de constatare a inexistenţei impedimentelor la căsătorie, certificatul de creştinare, declaraţia privind libertatea matrimonială, certificatul de anulare a căsătoriei de către biserica catolică, în cazul unei căsătorii anterioare desfăcute, hotărârea de divorţ, în cazul unei căsătorii anterioare desfăcute pe cale judecătorească, declaraţiile a 2 martori, certificatul de confirmare religioasă, cartea de identitate și certificatul de participare la cursul precanonic organizat de biserică.

Căsătoria religioasă trebuie înregistrată, în registrul de căsătorii, de ofiţerul de stare civilă competent teritorial, imediat după primirea certificatului pe care oficiantul căsătoriei îl trimite în termen de 5 zile de la oficierea căsătoriei. Preoţii care oficiază căsătorii răspund civil pentru nerespectarea condiţiilor legale referitoare la încheierea căsătoriei religioase.

În Portugalia, ceremoniile de căsătorie romano-catolice pot avea loc în orice biserică autorizată în acest scop, conform legilor 
canonice. Căsătoria romano-catolică nu trebuie precedată de căsătoria civilă. Potrivit art.1070 din Codul civil $^{73}$, legea canonică "defineşte şi reglementează condiţiile şi efectele spirituale ale căsătoriei", în timp ce legea civilă "defineşte şi reglementează condiţiile şi efectele temporale ale căsătoriei."

Ceremoniile de căsătorie oficiate de alte biserici sau culte sunt precedate de căsătoria civilă, în urma căreia se emite certificatul de căsătorie (art.1057 din Codul civil). Precizăm că apare textual menționat în codul civil, la art.1056: Căsătoria este un contract permanent între două persoane de sex diferit, încheiat în scopul constituirii legitime a unei familii. Catolicii celebrează căsătoria în forma stabilită de Biserica catolică. Cei care nu sunt catolici celebrează căsătoria în faţa ofițerului de stare civilă, în condiţiile şi în formele stabilite de legea civilă. Preotul care oficiază o căsătorie prin încălcarea dispoziţiilor legale, este sancţionat cu pedepsele prevăzute de legea penală.

În Slovacia, căsătoria religioasă oficiată, în condiţiile prevăzute de lege, de autorităţile bisericeşti autorizate în acest scop, are efecte legale. Căsătoria religioasă se oficiază, în prezenţa a 2 martori, de persoana autorizată de aşezământul religios înregistrat, în condiţiile dreptului canonic. Conform art.10 din Tratatul încheiat, în anul 2000, cu Vaticanul, oficierea căsătoriilor catolice este guvernată de legea canonică. În termen de 3 zile de la oficierea căsătoriei, preotul oficiant obligaţia de a trimite certificatul de căsătorie la biroul de stare civilă competent teritorial, în vederea înregistrării.

În Spania, legea organică nr.7/1980 privind libertatea religioasă prevede dreptul comunităţilor religioase de a încheia acorduri cu statul pentru reglementarea unor instituţii religioase specifice, printre care şi căsătoria religioasă cu efecte legale. În anul 1992, trei comunităţi religioase (protestantă, evreiască şi musulmană) au încheiat acorduri de cooperare cu statul. Astfel, legea recunoaşte legalitatea şi validitatea căsătoriilor religioase catolice, protestante,

${ }^{73}$ Code Civil Portugais, http://www.juristoria.com/resources/CODE+CIVIL+PORTUGAIS.doc (accesat în martie 9, 2016) 


\section{$15^{\text {th }}$ International Symposium on Science, Theology and Arts}

evreieşti şi musulmane. ${ }^{74}$ Conform Codului civil ${ }^{75}$ şi acordurilor încheiate de comunităţile religioase cu statul, căsătoria religioasă îşi produce efectele legale din momentul oficierii. Pentru recunoaşterea deplină a efectelor legale, certificatul căsătoriei religioase eliberat de biserică trebuie înregistrat în registrul de stare civilă competent teritorial.

În Spania, țară majoritar catolică, s-a păstrat tradiţia catolică. Căsătoria catolică nu necesită proceduri civile preliminare. În vederea încheierii căsătoriei religioase, viitorii soţi trebuie să prezinte preotului oficiant autorizat certificatele de naştere, certificatele de creştinare și certificatele de libertate matrimonială. În termen de o săptămână de la oficierea căsătoriei religioase, certificatul de căsătorie religioasă trebuie trimis la biroul de stare civilă competent teritorial pentru înregistrare. Solicitarea înregistrării poate fi făcută atât de către soţi, cât şi de preotul oficiant. Neînregistrarea căsătoriei nu aduce atingere validităţii căsătoriei.

Cuplurile care se căsătoresc în cadrul unei ceremonii protestante, islamice sau evreieşti trebuie să obţină întâi autorizaţia de căsătorie emisă de autorităţile de stare civilă competente. Anterior oficierii căsătoriei, viitorii soţi trebuie să se prezinte la funcţionarul biroului de stare civilă competent teritorial. După verificarea capacităţii civile de căsătorie a părţilor contractante, acesta eliberează certificatul de capacitate care permite viitorilor soţi să oficieze căsătoria având efecte civile, în termen de 6 luni de la emitere, în faţa preotului comunităţii religioase în cauză şi a 2 martori. Înregistrarea căsătoriei oficiate în Spania în formă religioasă se efectuează prin simpla înregistrare a certificatului emis de respectiva biserică, care trebuie să conţină elementele prevăzute de legislaţia privind registrul de stare civilă.

\footnotetext{
${ }^{74}$ A se vedea Zoila Combalia, Maria Roca, Religion and the Secular State of Spain, International Center for Law and Religious Studies http://www.iclrs.org/content/blurb/files/Spain.2a.pdf (accesat în martie 5, 2016)

${ }^{75}$ Spanish Civil Code, www.mjusticia.gob.es/ (accesat în martie 15, 2016)
} 
În Suedia, comunităţile religioase înregistrate în condiţiile Legii privind comunităţile religioase ${ }^{76}$, au dreptul de a oficia căsătorii religioase cu efecte legale depline. Conform dispoziţiilor legale, statul poate delega unei comunităţi religioase, competenţa administrativă de drept public a oficierii căsătoriei religioase cu efecte civile depline. Ceremonia religioasă se efectuează în conformitate cu procedura de căsătorie specifică comunităţii religioase în cauză. Căsătoria religioasă oficiată într-un aşezământ al Bisericii naţionale, Biserica luterană, poate fi oficiată numai dacă unul sau ambii viitori soţi sunt membri ai bisericii luterane. Bisericile au competenţa emiterii certificatelor de căsătorie.

În România, Constituția prevede în art.48 faptul că poate fi celebrată căsătoria religioasă doar după căsătoria civilă. Astfel, căsătoria poate fi una civilă și religioasă, căsătoria religioasă fiind facultativă.

Deputatul UDMR Szabő Ődőn este iniţiatorul unei propuneri legislative, alături de alți trei parlamentari UDMR și un parlamentar din grupul minorităților naționale, propunere prin care se dorește modificarea Legii 119/1996 cu privire la actele de stare civilă. Propunerea de modificare vizează posibilitatea ca viitorii soți care doresc celebrarea căsătoriei civile și a celei religioase în același loc, într-un lăcaș de cult, să poată să facă acest lucru. Astfel, toate documentele necesare si toată procedura preliminară rămân valabile doar că, viitorii soți pot opta ca ofițer de stare civilă să fie preotul care oficiază căsătoria religioasă, în lăcașul de cult.

Legea cultelor nr.486/2006 privind la libertatea religioasă și regimul general al cultelor este aceea care specifică în mod clar, cultele religioase recunoscute în România, astfel încăt lăcaș de cult în care s-ar putea celebra căsătoria religioasă este unul care aparține cultelor recunoscute. Pe de alta parte și condiţia prezenței celor doi martori rămâne una valabilă. Se schimbă doar locul oficierii căsătoriei și persoana care face acest lucru. Modelul urmat este cel al

\footnotetext{
${ }^{76}$ Act on religious communities signatures nr.1987:230 http://www.government.se/content/1/c6/02/78/31/04636561.pdf (accesat în martie 22, 2016)
} 


\section{$15^{\text {th }}$ International Symposium on Science, Theology and Arts}

Sloveniei. Iniţiatorul proiecului, deputatul UDMR Szabő Ödőn arată că, potrivit prevederilor legale, ofițeri de stare civilă pot fi șefii misiunilor diplomatice și ale oficiilor consulare de carieră ale României, comandanții de nave și aeronave, deci cu atât mai mult, susține el, clericii, în baza modificărilor legale, pot deveni ofițeri de stare civilă fără a deveni funcționari publici sau personal aflat în subordinea autorităților administrative locale.

Consiliul Legislativ al României, în luna ianuarie 2015 a avizat favorabil propunerea legislativă cu câteva observații și propuneri. În esență, viitorii soți pot astfel opta pentru celebrarea casatoriei civile și a celei religioase de aceeași persoană, un preot sau personal clerical al unui cult recunoscut în România. Testul propunerii legislative arată că documentația necesară încheierii căsătoriei cuprinde chiar actul de căsătorie completat de ofițerul de stare civilă de la serviciul public comunitar de evidență a persoanelor dar fără semnaturile celor doi martori și a preotului care oficiază căsătoria. Odată celebrată căsătoria, în termen de trei zile lucrătoare, soții trebuie să depună actul de căsătorie cu toate semnăturile pentru a le fi înmânat după înregistrarea în registru, certificatul de căsătorie. Dacă nu se respectă aceasta obligație se consideră căsătoria ca fiind neîncheiată și fără efecte juridice. Consiliul Legislativ a avizat favorabil dar propune ca preotul care oficiază casătoria să o înregistreze provizoriu într-un registru special ținut de unitatea de cult, urmând ca ea să producă efecte juridice și să aibe caracter definitiv doar după întocmirea actului de stare civilă la serviciul public comunitare de evidență a persoanelor.

Considerăm că este fericită soluția care ar da posibilitatea ca certificatul de căsătorie să fie remis imediat mirilor după celebrare, de către preot, astfel încât să producă efecte juridice imediat după exprimarea consimțământului la căsătorie. Preotul transmite certificatul si toate mențiunile legale autorității dar, înregistrările ulterioare nu afectează valabilitatea casatoriei ce își produce efecte imediat. Desigur trebuie modificate amplu prevederile legii actelor de stare civilă sub aspectul întocmirii certificatului de căsătorie ca act valabil în condițiile în care preotul este ofițer de stare civilă. 
În martie 2015, Guvernul României și-a exprimat un punct de vedere raportat la propunerea legislativă. Punctul de vedere este unul negativ și invocă motivele pentru care nu poate fi ofițer de stare civilă preotul și nu consideră propunerea ca fiind una sustenabilă ci una care lăsă loc interpretărilor și ambiguităților. La data de 04.05.2015 propunerea legislativă a fost respinsă în Senat iar la data curentă, ea este transmisă Camerei Deputaților pentru a fi supusă dezbaterii. Camera Deputaților este cameră decizională.

\section{Concluzii}

În unele state membre UE doar căsătoria civilă produce efecte legale, căsătoria religioasă nefiind legal recunoscută. Astfel, căsătoria civilă, efectuată de autorităţile de stare civilă teritorial competente, poate fi urmată sau nu de o ceremonie religioasă. Această situație o regăsim în Austria, Belgia, Bulgaria, Estonia, Franța, Lituania, Luxemburg, Olanda, Slovenia.

În Cehia, Cipru, Danemarca, Finlanda, Germania (din 2009, în anumite condiţii), Grecia, Irlanda, Italia, Letonia, Malta, Marea Britanie, Polonia, Portugalia, Slovacia, Spania şi Suedia căsătoria religioasă are efecte civile legale. Încheierea căsătoriei religioase este guvernată atât de legislaţia statului, cât şi de reglementările religioase specifice.

În România, remarcăm faptul că tinerii, în condițiile în care societatea a urmat un anume parcurs de tehnologizare, sunt supuși unor influențe care nu sunt percepute cu întregul lor efect. Legat de căsătoria religioasă, deseori aceștia nu înțeleg semnificația profundă a acesteia și o percep doar ca pe o formalitate care trebuie îndeplinită. Considerăm cu atât mai mult că se impune ca viitorii miri să își asume responsabilitățile în cunoștință de cauză și nu din inerție. Educația religioasă cu privire la cununia religioasă este o necesitate iar propunerea legislativă inițiată de deputatul Szabő Ödőn este binevenită și îndrăznim chiar să afirmăm că are o altă semnificație DA-ul rostit într-un lăcaș de cult, în fața unui ofițer de stare civilă, 
preot. Pe de altă parte, autoritatea legislativă ar trebui să ia în calcul posibilitatea de a conferi recunoaştere legală actului de cununie religioasă ca act civil cu efecte juridice depline.

\section{Bibliografie}

1. Martine Segalen, Historical Anthropology of the Family, Melbourne, 2002

2. Arnold von Ghennep, The Rites of Passage, London, 2004

3. Pierre Sauzeau, André Sauzeau, La quatrième fonction: altérité et marginalité dans l idéologie des Indo-Européens. Vérité des mythes, Les Belles Lettres, Paris, 2012

4. James Parsons, The Ancient Commonwealth, in American Law Register, vol XX, Philadelphia, 1972

5. Michael Fontaine, Adele C. Scafuro, The Oxford Handbook of Greek and Roman Comedy, Oxford University Press, New York, 2014

6. Marcus Tullii Ciceronis, De Legibus Libri, II, 19, ediţie îngrijită de Iohannis Vahleni, Berolini, 1883

7. William Smith, A Smaller Dictionary of Greek and Roman Antiquities, London, 1868

8. Graham Anderson, Greek and Roman Folklore: A Handbook, Greenwood Press, London, 2006

9. Henry George Liddell, Robert Scott, Henry Drisler, A Greek-English Lexicon, volumul IX, 1883

10. Bruce W. Frier, Thomas A. J. McGinn, Thomas A. McGinn, $A$ Casebook on Roman Family Law, Oxford University Press, New York, 2004

11. Brian K. Harvey, Daily Life in Ancient Rome: A Sourcebook, Indianapolis, 2016

12. Epitola către Diognet, V, 1-10, în Scrierile Părinţilor Apostolici, trad. de Pr. dr. Dumitru Fecioru, Editura Institutului Biblic şi de Misiune al Bisericii Ortodoxe Române, Bucureşti, 1995,

13. Sfầntul Ignatie Teoforul, Către Policarp, 5, 1, în Scrierile Părinţilor Apostolici, trad. de Pr. D. Fecioru, Editura Institutului Biblic şi de Misiune al Bisericii Ortodoxe Române, București, 1979

14. Jean Gaudémet, Le mariage en Occident: les moeurs et le droit, Les Éditions du Cerf, Paris, 1987

15. Gabriel Le Bras, Jean Gaudemet Sirey, Histoire $d u$ droit et des institutions de l'Église en Occident, volumul III, Paris, 1955

16. St. Gregory of Nazianz, Lettres, trad. P. Gallay, Paris, 1967 
17. Pr. Lector Dumitru Radu, Caracterul eclesiologic al Sfintelor Taine şi problema intercomuniunii, în Ortodoxia, nr. 1-2(1978)

18. Lucien Anné Desclée, Les rites des fiançailles et la donation pour cause de mariage sous le Bas-Empire, L

19. Alexander P. Kazhdan ed., The Oxford Dictionary of Byzantium, vol. I, New York, 1990

A. Arjava, Women and Law in Late Antiquity, Oxford, 1996

20. Theophylactus Simocattas, Historiae, I, 10, 2-4, ed. C. de Boor, Leipzig, 1887

21. M. T. G. Humphreys, Law, Power, and Imperial Ideology in the Iconoclast Era: C.680-850, oxford, 2015

22. Ecloga Leonis et Constantini, Epanagoge Basilii Leonis et Alexandri, în Collectio Librorum Juris Graeco-Romani, ed. Carolus Eduardus Zachariae a Lingenthal, Lipsiae, 1852

23. P. P. Joannou, Discipline generale antique, tome I, Les canons des conciles oecuméniques (II-IX s.), Grottaferrata, 1982

A. Dain, Les Nouvelles de Leon VI le Sage, Paris, 1944,

24. John Meyendorff, Căsătoria perspectiva ortodoxă, ediţia a doua, traducere de Cezar Login, Editura Renaşterea/ Editura Patmos, Cluj Napoca, 2012

25. P. Noailles - A. Dain, Les Novelles de Léon VI le Sage, Paris, 1944

26. Arhid. prof. dr. Ioan N. Floca, Drept canonic ortodox, legislaţie şi administraţie bisericească, vol. II, Editura Institutului Biblic şi de Misiune al Bisericii Ortodoxe Române, Bucureşti, 1990

27. V. Grumel, Les Regestes des actes du Patriarchat de Constantinople, Le patriarcat byzantin, series 1, Constantinople, 1936

28. K. Ritzer, Le Mariage dans les Eglises chrétiennes du Ier au IX siècle, Paris, 1962

29. Nicolae Iorga, Byzance après Byzance, Continuation de l'Histoire de la vie byzantine, Bucarest, 1971; Vasile Lupu ca urmätor al impăraţilor de Răsărit în tutelarea Patriarhiei de Constanlinopole şi a Bisericii ortodoxe, în Academia Română. Memoriile secţiunii istorice, nr. 36 (1913-1914); Muntele Athos în legătură cu ţările noastre, în Academia Română. Memoriile secţiunii istorice, nr. 36 (1913 -1914); Fundaţile religioase ale domnilor români în Orient, în Academia Română. Memoriile secţiunii istorice, nr. 36 (1913-1914); Donaţiile româneşti pentru mănăstirile din Marea Marmara, în Revista istorică, nr. 7(1921); Legăturile româneşti cu Muntele Sinai, în Academia Română. Memoriile secţiunii istorice, nr. 3 (1932-1933); Domnitorii români Vasile Lupu, Şerban Cantacuzino şi Constantin Brâncoveanu 
în legătură cu patriarhii Alexandnei, în Academia Română. Memoriile secţiunii istorice, seria a Ill-a, nr. 13 (1932-1933)

30. Valentin A. Georgescu, L'idée impériale byzantine et la réaction des réalités roumaines (XIVe-XVIIIe siècle). Idéologie politique, structuration de l'Etat et du droit, în Byzantina, nr. 3 (1971), Byzance et les institutions roumaines jusqu à la fin $d u X V$ e siècle, în Actes du XlVe Congrès international des études byzantines, Bucarest, 1971

31. Pan. J. Zepos, Byzantine Law in the Danubian Countries, în Balkan Studies, 7 (1966)

32. Lucian Predescu, Contribuţie la viaţa şi opera lui Dragoş-Eustratie Logofătul, în Glasul Bisericii, nr. 28 (1969), nr. 9-10

33. Alin-Mihai Gherman, Profil cultural. Eustratie Logofătul, în Un veac de aur în Moldova (1643-1743), Bucureşti-Chişinău, 1996

34. Carte romînească de învătătură 1646, ediţie îngrijită de Andrei Rădulescu, Editura Academiei Republicii Populare Romîne, Bucureşti, 1961

35. Pravila bisericească numită cea mică, în Colecţiune de legiuirile României vechi şi celei noui, ed. de Ioan M. Bujoreanu, vol. III, Tipografia Academiei Române, Bucureşti, 1885

36. Indreptarea Legii 1652, colecţie îngrijită de Acad. Andrei Rădulescu, Editura Academiei Republicii Populare Romîne, Bucureşti, 1962

37. Andreiu Şaguna, Compendiu de drept canonic al unei Sântei Soborniceşti şi Apostoleşti Biserici, ed. a III-a, Sibiu, 1913

38. Legiuirea Caragea, Tipografia Naţională a lui Ştefan Rassidescu, București, 1865

39. Ioan M. Bujoreanu, Colecţiune de legiuirile României câte s au promulgatu pene la finele anului 1870, Noua Typographie a Laboratoriloru Români, Bucuresci, 1873

40. Alecsandru Ion I., Codice civile, Imprimeria Statului, Bucuresci, 1865

41. Mircea Brie, Reglementări juridice privitoare la familie în legislaţia austriacă şi maghiară din a doua jumătate a secolului al XIX-lea, în vol. Politici imperiale în estul şi vestul spaţiului românesc, Editura Universităţii din Oradea/Editura Cartdidact, Oradea/Chişinău, 2010

42. Charalambos K. Papastathis, Greece: A Faithful Orthodox Christian State. The Orthodox Church in the Hellenic Republic, International Center for Law and Religious Studies

43. Zoila Combalia, Maria Roca, Religion and the Secular State of Spain, International Center for Law and Religious Studies 


\section{Legislație:}

44. Codul Civil din Germania, Grecia, Irlanda, Letonia, Spania, Portugalia

45. Codul Familiei din Polonia

46. Legea privind căsătoria din Cehia, Danemarca, Cipru, Finlanda, Marea Britanie, Grecia

47. Tratatele Sloveniei, Italiei, Poloniei și Malta cu Vaticanul

48. Commission Internationale de l'État Civil, Guide pratique international de l'état civil - Grèce 